\title{
PROFIL MODALITAS BELAJAR MAHASISWA PROGRAM STUDI PENDIDIKAN BIOLOGI
}

\author{
Titin \\ Program Studi Pendidikan Biologi FKIP Universitas Tanjungpura \\ Jalan Prof. Dr. Hadari Nawawi Pontianak \\ e-mail: titinbasuki@rocketmail.com
}

\begin{abstract}
Abstrak
Penelitian ini bertujuan untuk mendeskripsikan profil modalitas belajar mahasiswa Pendidikan Biologi. Adanya informasi mengenai modalitas belajar mahasiswa akan mempengaruhi apa yang harus dilakukan dosen sebagai tolak ukur keberhasilan pembelajaran. Metode penelitian yang digunakan adalah deskriptif. Subjek penelitian adalah mahasiswa pendidikan biologi FKIP Universitas Tanjungpura berjumlah 95 orang.Instrumen yang digunakan dalam penelitian ini berupa angket/kuesioner modalitas belajar dalam bentuk skala likert. Hasil penelitian menunjukkan mahasiswa kelas A didominasi modalitas belajar visual sebesar 61,76 $\%$., kelas B didominasi modalitas belajar visual sebesar 96,55 \% dan kelas PPAPK didominasi modalitas belajar visual sebesar 93,75\%. Secara keseluruhan modalitas belajar mahasiswa pendidikan biologi didominasi oleh modalitas belajar visual sebesar $83,16 \%$.
\end{abstract}

Kata Kunci: modalitas belajar, mahasiswa, pendidikan biologi

\begin{abstract}
The purpose of this research was to describe the profile of learning modality for Biology Education students. There is information about students' learning modality influenced what lecturer has to do as a key to the success of learning.The method of this research is descriptive. The subjects of the research were the students of biology education of FKIP Tanjungpura University with the total number 95 people. The instrument of this research was questionnaire/learning modality was likert scale. The result showed that A class students dominated visual learning modality of $61.76 \%$, B class was dominated by visual learning modality of $96.55 \%$ and class of PPAPK was dominated by visual learning modality of 93.75\%.Overall learning modalities of biology education students was dominated by visual learning modality of $83.16 \%$.
\end{abstract}

Keyword: learning modalities, student, biology education

\section{PENDAHULUAN}

Pendidik (dosen) dalam proses pembelajaran berperan untuk membantu peserta didik (mahasiswa) untuk memperoleh informasi (pengetahuan) atau ide, meningkatkan keterampilan, dan memperbaiki sikap (nilai). Untuk itu saat proses pembelajaran berlangsung, dosen diharapkan dapat membantu mahasiswa agar dapat belajar dengan efektif dan mudah. 
Pembelajaran yang efektif menuntut keterlibatan peserta didik secara aktif, karena merupakan pusat kegiatan pembelajaran dan pembentukan kompetensi. Peserta didik harus didorong untuk menafsirkan informasi yang disajikan oleh guru sampai informasi tersebut dapat diterima oleh akal sehat dalam pelaksanaannya (Hasrul, 2009). Pembelajaran yang berlangsung juga diharapkan dapat mendorong kreativitas mahasiswa, membuat mahasiswa aktif, mencapai tujuan pembelajaran secara efektif dan berlangsung dalam kondisi yang menyenangkan.

Untuk mewujudkan pembelajaran yang efektif, hal yang harus diketahui seorang dosen adalah mengetahui modalitas belajar atau gaya belajar mahasiswanya. Mahasiswa merupakan individu yang unik dengan kebutuhan dan latar belakang yang unik pula. Menurut Hasrul (2009) tiap mahasiswa mempunyai perbedaan satu dengan yang lain. Perbedaan itu terdapat pada karakteristik psikis, kepribadian, dan sifat-sifatnya. Perbedaan individual ini berpengaruh pada cara belajar dan hasil belajar mahasiswa. Karenanya, perbedaan individual perlu diperhatikan oleh dosen dalam upaya pembelajaran.

Hasrul (2009) menyatakan bahwa modalitas belajar atau gaya belajar merupakan suatu kombinasi dari bagaimana seseorang menyerap dan kemudian mengatur serta mengolah informasi. Gaya belajar bukan hanya berupa aspek ketika menghadapi informasi, melihat, mendengar, menulis dan berkata tetapi juga aspek pemrosesan informasi sekunsial, analitik, global atau otak kiri dan otak kanan. Aspek lain adalah ketika merespon sesuatu atas lingkungan belajar (diserap secara abstrak dan konkret). Suyono dan Hariyanto (2011) menyatakan bahwa seorang anak yang memahami modalitas belajarnya sendiri akan memperoleh manfaat dalam pembelajarannya karena dia akan biasa dengan cara belajar yang cocok bagi dirinya sendiri.

Dari hasil observasi yang dilakukan oleh peneliti dalam proses pembelajaran mahasiswa program studi Pendidikan Biologi FKIP Untan, dapat diketahui sistem pendidikan klasikal yang dilaksanakan selama ini belum memperhatikan masalah perbedaan individual, umumnya pelaksanaan pembelajaran di kelas dengan melihat mahasiswa sebagai individu dengan 
kemampuan rata-rata, kebiasaan yang kurang lebih sama, demikian pula dengan pengetahuannya. Proses pembelajaran yang demikian menyebabkan mahasiswa belum belajar secara efektif.

Modalitas belajar atau yang sering dikenal dengan istilah gaya belajar peserta didik dibedakan menjadi tiga yaitu visual, auditori, dan kinestetik. Sari (2014) menyatakan sebagian peserta didik bisa belajar dengan sangat baik hanya dengan cara melihat orang lain melakukannya. Mereka menyukai cara penyajian informasi yang runtut. Selama pelajaran, peserta didik tersebut suka menulis apa yang dikatakan pendidik/guru/dosen. Peserta didik visual ini berbeda dengan peserta didik auditori yang mengandalkan kemampuan untuk mendengar. Sedangkan peserta didik kinestetik lebih suka belajar dengan cara terlibat langsung.

Adanya informasi mengenai modalitas belajar mahasiswa akan mempengaruhi apa yang harus dilakukan dosen terhadap materi pembelajaran (kurikulum), pengajaran, dan penilaian sebagai tolak ukur keberhasilan pembelajaran. Dosen wajib mengenali modalitas belajar setiap mahasiswa kemudian dilihat mana modalitas belajar yang paling dominan, hal itulah yang harus disesuaikan dengan metode pembelajarannya. Demikian juga pendidik yang memahami modalitas belajar setiap individu akan mampu memilih metode pembelajaran yang bermakna bagi anak didiknya.

Penelitian ini bertujuan untuk mengetahui profil modalitas belajar mahasiswa Program Studi Pendidikan Biologi FKIP Universitas Tanjungpura. Diperolehnya informasi mengenai modalitas belajar mahasiswa maka diharapkan dapat dapat diciptakan proses pembelajaran yang efektif dan menyenangkan.

\section{METODE}

Penelitian ini menggunakan metode penelitian deskriptif yang bertujuan untuk mengungkapkan keadaan yang sebenarnya mengenai profil modalitas belajar mahasiswa program studi Pendidikan Biologi FKIP Universitas Tanjungpura Pontianak. Subjek penelitian ini adalah seluruh mahasiswa Program 
Studi Pendidikan Biologi FKIP Universitas Tanjungpura yang berada di semester 3. Adapun jumlah subjek penelitian sebanyak 95 orang.

Teknik pengumpulan data dalam penelitian ini menggunakan non tes. Teknik non tes yang digunakan berupa angket/kuesioner. Menurut Riduwan (2011) angket/kuesioner terstruktur merupakan angket yang disajikan dalam bentuk sedemikian rupa sehingga responden diminta untuk memilih satu jawaban yang sesuai dengan karakteristik dirinya dengan cara memberi tanda silang atau tanda checklist. Angket digunakan untuk melihat persepsi mahasiswa. Penyusunan angket/kuesioner dimulai dengan analisis variabel, membuat kisi-kisi dan menyusun pertanyaan (Sudjana, 2006). Sebelum digunakan angket diuji validitas terlebih dahulu. Menurut Sugiyono (2014) validitas merupakan derajat ketepatan antara data yang terjadi pada objek penelitian dengan data yang dilaporkan oleh peneliti. Lembar validasi merupakan lembar yang digunakan untuk mengumpulkan data tentang pendapat dan masukan dari para ahli. Jenis pengujian validitas yang digunakan dalam penelitian ini adalah validitas isi (content validity). Dari hasil penilaian validator, maka dapat diketahui bahwa angket yang dibuat layak digunakan dengan perbaikan.

Cara penyampaian angket adalah diberikan langsung pada mahasiswa sebelum dimulainya proses pembelajaran pada semester 3. Data angket yang diperoleh dari setiap responden akan dibuat rekapitulasinya berdasarkan masingmasing modalitas belajar. Analisis data yang digunakan merujuk pada Sari (2014). Berikut ini beberapa langkah dalam analisis data tersebut:

1. Terdapat beberapa pertanyaan dalam instrumen angket yang akan diisi oleh respon. Terdapat 3 kelompok pertanyaan yang mencerminkan masing-masing modalitas belajar, yaitu kelompok modalitas belajar "V" (Visual), kelompok modalitas belajar "A" (Auditorial), dan kelompok modalitas belajar "K" (kinestetik). Setiap pertanyaan memiliki jawaban pilihan yaitu: "sering" diberi skor 2, "kadang-kadang” diberi skor 1, dan "jarang” diberi skor 0.

2. Dari masing-masing kelompok pertanyaan modalitas belajar, skor tersebut dijumlah sehingga pada tiap-tiap kelompok pertanyaan modalitas belajar akan menghasilkan suatu nilai tertentu. 
3. Penarikan kesimpulan kecenderungan modalitas belajarnya dengan cara membandingkan tiga nilai masing-masing kelompok pertanyaan yang diisi oleh subjek tersebut. Penarikan kesimpulan didasarkan pada:

a) Jika terdapat nilai tertinggi pada suatu kelompok pertanyaan modalitas belajar, maka disimpulkan subjek tersebut cenderung dominan pada modalitas belajar tersebut;

b) Jika terdapat dua nilai tertinggi yang sama dari dua kelompok pertanyaan modalitas belajar, maka subjek tersebut tergolong pada pada "Gabungan kedua modalitas belajar" tersebut.

c) Jika terdapat dua nilai tertinggi dari dua kelompok pertanyaan gaya belajar yang berselisih 1 poin, maka subjek tersebut tergolong pada pada "Gabungan kedua modalitas belajar" tersebut.

4. Setelah itu, akan dibuat rekapitulasi berupa:

a) Persentase kecenderungan modalitas belajar dari masing-masing kelas mahasiswa Program Studi Pendidikan Biologi

b) Persentase kecenderungan modalitas belajar secara keseluruhan dari mahasiswa.

\section{HASIL DAN PEMBAHASAN}

Dari penelitian yang telah dilakukan, diperoleh informasi bahwa modalitas belajar yang dimiliki oleh mahasiswa sangat berbeda-beda, ada yang memiliki modalitas belajar auditorial, dan ada juga modalitas belajar kinestetik. Dari angket/kuisioner yang telah diberikan dan setelah data angket tersebut dianalisis, diketahui bahwa modalitas belajar mahasiswa pendidikan biologi FKIP Untan sangat beragam, ada yang memiliki modalitas belajar visual, auditorial, dan ada juga yang memiliki modalitas belajar kinestetik. Berdasarkan analisis data yang telah dilakukan dari tiga gaya belajar yang ada yaitu visual, auditori dan kinestetik. Modalitas belajar yang dimiliki oleh mahasiswa pendidikan biologi FKIP Untan didominasi oleh modalitas belajar visual. Modalitas belajar mahasiswa Pendidikan Biologi disajikan pada Tabel 1. 
Tabel 1. Modalitas Belajar Mahasiswa Pendidikan Biologi

\begin{tabular}{clll}
\hline Kelas & $\begin{array}{l}\text { Modalitas } \\
\text { Belajar }\end{array}$ & Frekuensi & $\begin{array}{l}\text { Persentase } \\
(\%)\end{array}$ \\
\hline A & Visual & 21 & 61,76 \\
& Auditori & 5 & 14,71 \\
& Kinestetik & 8 & 23,53 \\
B & Visual & 28 & 96,55 \\
& Auditori & 0 & 0 \\
PPAPK & Kinestetik & 1 & 3,45 \\
& Visual & 30 & 93,74 \\
& Auditori & 1 & 3,13 \\
Total mahasiswa & Kinestetik & 1 & 3,13 \\
\hline
\end{tabular}

Berdasarkan penelitian yang telah dilakukan dapat diketahui bahwa modalitas belajar visual, auditorial, dan kinestetik merupakan suatu kombinasi cara mahasiswa dapat menyerap, mengatur, dan mengolah informasi. Dari penelitian ini dapat dilihat bahwa kecenderungan seseorang untuk belajar sangat beragam, begitu juga dengan modalitas belajar serta cara untuk menerima informasi yang diperoleh dari proses pembelajaran pada masing-masing anak sangat beragam. Hal ini sejalan dengan pendapat Bire, dkk (2014) yang menyatakan bahwa modalitas belajar/tipe belajar adalah cara seseorang menyerap informasi, mengelolanya, dan memanifestasikan dalam wujud nyata perilaku hidupnya.

Modalitas belajar mahasiswa yang bervariasi ini dapat mempengaruhi cara dosen menyampaikan materi pembelajaran. Berdasarkan pendapat Suyono dan Hariyanto (2011) belajar adalah suatu aktivitas atau suatu proses untuk memperoleh pengetahuan, meningkatkan keterampilan, memperbaiki perilaku, siikap, dan pengkokohkan kepribadian. Dengan adanya modalitas belajar yang beragam ini dosen dituntut untuk lebih pandai memilih stategi, metode, dan model pembelajaran yang sesuai dengan kemampuan belajar serta modalitas belajar yang dimiliki dengan materi yang akan disampaikan, sehingga mahasiswa yang memiliki modalitas belajar yang beragam ini dapat mengikuti proses pembelajaran dengan baik. 
Modalitas belajar merupakan salah satu faktor penting yang dapat mempengaruhi hasil belajar, sehingga mengetahui modalitas belajar yang dimiliki oleh mahasiswa sangat penting diketahui terlebih dahulu oleh dosen. Tujuan dosen mengetahui modalitas belajar mahasiswa yaitu agar dapat menjadi panduan untuk merancang pembelajaran yang sesuai dengan modalitas belajar mahasiswa sehingga dapat meningkatkan kemampuan mahasiswa dalam menyerap dan mengelola serta mengatur informasi yang diperolehnya dengan baik.

Modalitas belajar visual merupakan salah satu modalitas belajar yang pada dasarnya lebih menekankan pada bagaimana mahasiswa lebih mudah menyerap pelajaran dengan cara melihat, atau mengamati objek secara langsung. Dari pengamatan dan analisis data, modalitas belajar visual menuntut mahasiswa untuk lebih fokus mengamati, mendengarkan dan melihat gerakan dosen ketika menjelaskan materi pembelajaran.

Modalitas belajar pada mahasiswa pendidikan biologi dominan pada modalitas belajar visual. Dimana modalitas belajar ini lebih cenderung belajar dengan cara melihat/mengamati secara langsung. Hal ini didukung oleh pendapat Ula (dalam Bire, dkk., 2014) yang menyatakan bahwa modalitas belajar visual adalah gaya belajar dengan melihat sesuatu, baik melalui gambar atau diagram, pertunjukan, peragaan, atau video.

Meskipun sebagian besar mahasiswa pendidikan biologi FKIP Untan memiliki modalitas belajar dominan, namun ditemukan juga ada beberapa mahasiswa yang memiliki modalitas belajar auditori dan kinestetik. Modalitas belajar auditori merupakan modalitas belajar yang lebih mengutamakan indra pendengaran. Modalitas belajar auditori ini biasanya mudah memahami apa yang dipelajari dengan cara mendengarkan suara, sehingga untuk mahasiswa yang memiliki modalitas belajar ini telinga adalah alat indra yang berperan penting dalam proses pembelajaran. Mahasiswa yang memiliki modalitas belajar auditorial dapat dilihat dari beberapa kebiasaanya yang dilakukan yaitu seperti belajar dengan cara mendengarkan dan mengingat dari pada melihat, berbicara sendiri pada saat bekerja atau belajar, mudah terganggu oleh keributan sehingga membuatnya sulit untuk berkomunikasi. Untuk mengatasi mahasiswa yang 
memiliki modalitas belajar auditori ini, menuntuk dosen ketika proses pembelajaran berlangsung, selain menggunakan metode serta strategi pembelajaran yang baik juga harus mempunyai suara yang besar agar semua mahasiswa dapat yang ada di dalam ruangan kelas dapat mendengarkan penjelasan dengan baik.

Modalitas belajar kinestetik merupakan modalitas belajar yang melalui gerakan. Menurut Suyono dan Haryanto (2011) modalitas belajar kinetetik, merupakan modalitas belajar dimana anak belajar melalui gerakan-gerakan fisik, seperti berjalan-jalan, mengerak-gerakan kaki atau tangan, melakukan eksperimen yang memerlukan aktivitas fisik dan sebagainya. Modalitas belajar anak yang termasuk modalita belajar kinetetik dapat dilihat dari kebiasaan anak ketika belajar, misalnya seperti banyak mengunakan istilah tubuh, menghafal dengan cara berjalan dan melihat, tidak dapat duduk diam dalam waktu yang lama. Anak yang memiliki gaya belajar kinetetik ini cenderung menyukai belajar dengan atau menerima informasi melalui gerakan atau sentuhan.

Berdasarkan penelitian yang telah dilakukan, dapat diketahui bahwa modalitas belalar mahasiswa pendidikan biologi sangat bervariasi sehingga menuntut dosen agar bisa lebih mengenal dan memahami karakteristik modalitas belajar dari masing-masing mahasiswanya sehingga proses belajar mengajar dapat berjalan dengan baik sesuai dengan modalitas belajarnya dan dapat menghasilkan prestasi belajar yang baik. Dengan adanya penelitian ini juga dapat digunakan oleh dosen sebagai panduan untuk merancang pembalajaran yang sesuai dengan modalitas belajar mahasiwanya. Bagi mahasiswa, penelitian inin juga sangat bermanfaat yaitu dapat memberi informasi tambahan mengenai modalitas belajar yang dimiliki masing-masing mahasiswa sehingga dapat menjadi panduan dalam belajar, serta dapat lebih memahami gaya belajar diri sendiri sehingga dapat memudahkan mahasiswa dalam menerimam menyerap dan mengatur informasi yang diperoleh. 


\section{SIMPULAN}

Secara keseluruhan modalitas belajar mahasiswa pendidikan biologi FKIP Universitas Tanjungpura, tertinggi adalah modalitas belajar visual sebesar 83,16\% sedangkan modalitas belajar terendah adalah auditori. Modalitas belajar mahasiswa Pendidikan Biologi FKIP Untan sangat bervariasi sehingga menuntut dosen agar bisa lebih mengenal dan memahami karakteristik gaya belajar dari masing-masing mahasiswanya sehingga proses belajar mengajar dapat berjalan dengan baik sesuai dengan modalitas belajarnya dan dapat menghasilkan prestasi belajar yang baik.

\section{UCAPAN TERIMA KASIH}

Penulis mengucapkan banyak terima kasih terutama kepada Fakultas yang telah memberikan dana untuk melaksanakan penelitian mandiri ini. Penulis juga mengucapkan banyak terima kasih kepada mahasiswa,dosen dan semua pihak yang telah membantu kelancaran penelitian ini.

\section{DAFTAR PUSTAKA}

Bire, dkk. 2014. Pengaruh Gaya Belajar Visual, Auditorial dan Kinestetik Terhadap Gaya Belajar Siswa. Jurnal Pendidikan. Volume 44 (2): 168-174.

Hasrul. 2009. Pemahaman Tentang Gaya Belajar. Jurnal MEDTEK. Volume 1 Nomor (2)

Riduwan. 2011. Skala Pengukuran Variabel-Variabel Penelitian. Bandung: Alfabeta

Sari, Ariesta Kartika. 2014. Analisis Karakteristik Gaya Belajar VAK (Visual, Auditory, Kinestetik) Mahasiswa Pendidikan Informatika Angkatan 2014. Jurnal Ilmiah Edutic, Volume 1 (1): 1-12.

Sudjana, Nana. 2006. Penilaian Hasil Proses Belajar Mengajar. Bandung: PT Remaja Rosdakarya

Suyono dan Hariyanto. 2011. Belajar dan Pembelajaran, Teori dan Konsep Dasar. Surabaya: PT. Remaja Rosdakarya

Sugiyono. 2014. Metode Penelitian Pendidikan Pendekatan Kuantitatif Kualitatif dan R\&D. Bandung: Alfabeta. 